\title{
Regulation of stream water dissolved organic carbon (DOC) concentrations during snowmelt; the role of discharge, winter climate and memory effects
}

\author{
A. Ågren ${ }^{1}$, M. Haei ${ }^{2}$, S. J. Köhler ${ }^{3}$, K. Bishop ${ }^{3}$, and H. Laudon ${ }^{1}$ \\ ${ }^{1}$ Dept. of Forest Ecology and Management, Swedish University of Agricultural Sciences, 90183 Umeå, Sweden \\ ${ }^{2}$ Dept. of Ecology and Environmental Science, Umeå University. 90187 Umeå, Sweden \\ ${ }^{3}$ Dept. of Aquatic Sciences and Assessment, Swedish University of Agricultural Sciences, P.O. Box 7050, \\ 75007 Uppsala, Sweden
}

Received: 18 June 2010 - Published in Biogeosciences Discuss.: 23 June 2010

Revised: 10 September 2010 - Accepted: 15 September 2010 - Published: 23 September 2010

\begin{abstract}
Using a 15 year stream record from a northern boreal catchment, we demonstrate that the inter-annual variation in dissolved organic carbon (DOC) concentrations during snowmelt was related to discharge, winter climate and previous DOC export. A short and intense snowmelt gave higher stream water DOC concentrations, as did long winters, while a high previous DOC export during the antecedent summer and autumn resulted in lower concentrations during the following spring. By removing the effect of discharge we could detect that the length of winter affected the modeled soil water DOC concentrations during the following snowmelt period, which in turn affected the concentrations in the stream. Winter climate explained more of the stream water DOC variations than previous DOC export during the antecedent summer and autumn.
\end{abstract}

\section{Introduction}

Dissolved organic carbon (DOC) is a fundamental descriptor of biogeochemical processes in small catchments and affects biogeochemical processes (Kalbitz et al., 2000), food web structure (Jansson et al., 2007) and the carbon balance (Cole et al., 2007; Nilsson et al., 2008). It is well established that hydro-climatic conditions control much of the episodic (Boyer et al., 1997), seasonal (Dawson et al., 2008) and interannual variability of DOC (Köhler et al., 2008), but also long term trends (Erlandsson et al., 2008). A warmer and wetter

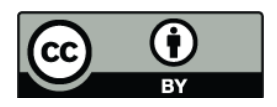

Correspondence to: A. Ågren

(anneli.agren@seksko.slu.se) climate has been predicted to result in an increase in stream DOC concentrations in many regions (De Wit and Wright, 2008; Köhler et al., 2009; Sebestyen et al., 2009). Much less is known about the snowmelt period, which is the most important hydrological period of the year in many seasonally snow covered regions. Given the large amount of runoff in the northern latitude catchments during this period, it is important to better understand what controls DOC concentrations at the transition period from winter to summer. Discharge has a strong influence on the concentrations during spring (Laudon et al., 2004a; Ågren et al., 2007; Seibert et al., 2009). However, it was only recently demonstrated that stream DOC concentrations also can be strongly controlled by winter climatic conditions (Haei et al., 2010). Climate change scenarios predict a change in the duration and timing of the snow-cover (IPCC, 2007). At the same time, regional climate models suggests that the temperature and precipitation will increase most in northern latitudes and during the winter months (Christensen et al., 2007). How this will affect the stream DOC concentrations and exports during snowmelt in the future is however not well understood.

In our glaciated forested study catchment the riparian soils are the most important source of carbon (Bishop et al., 1994; Köhler et al., 2009; Seibert et al., 2009). A shallow water table adjacent to the stream results in anaerobic conditions with a low decomposition rate; hence resulting in a build-up of organic material which leads to a peat formation along the stream channel (Vidon et al., 2010). As the water moves laterally through a riparian peat the concentrations of organic carbon increase markedly before it enters the stream (Bishop et al., 1990). According to Hinton et al. (1998) the riparian zone can contribute as much as $84 \%$ of DOC during a storm

Published by Copernicus Publications on behalf of the European Geosciences Union. 
and according to Dosskey and Bertsch (1994), the riparian organic peat can provide $93 \%$ of the stream organic carbon despite covering only $6 \%$ of the catchment area. There is also a seasonal variation in the soil water concentrations which increase during the snow free period and are at their minimum at the time of snowmelt (Seibert et al., 2009).

When new water (precipitation or snowmelt) enters into the catchment during a rain or snowmelt event, it recharges the soils and replaces so called old or previously stored water from the soil which is in turn moved into the stream. In forested glaciated watersheds with till soils, between 70 $90 \%$ of the water that enters the stream during snowmelt is old water (Rodhe, 1989; Laudon et al., 2007). Given the fact that soil water DOC concentrations increase upward in the soil profile, the lateral transport of DOC from soil to stream will increase if the water entering the streams is draining shallower more organic rich soil horizons (Inamdar et al., 2004; Sebestyen et al., 2008).

Discharge has a fundamental control on stream water DOC concentrations (Hornberger et al., 1994; Ågren et al., 2007; Dawson et al., 2008; Köhler et al., 2009). But, it is not the only controlling factor. The conditions in the soil before a rain or snowmelt event affect the concentrations during the event. During the vegetation period the soil moisture is important for the DOC leaching, but drying and rewetting have produced conflicting results. Inamdar et al. (2008) found higher DOC concentrations after a drought period, while Köhler et al. (2009) found that rain events during wet years lead to much higher DOC concentrations than during the dry years. In the autumn input of fresh leaf litter to the soils has been suggested to lead to higher DOC concentrations (Hongve, 1999). Flushing of the soils can deplete the amount of leachable carbon in the soil and lead to decreasing concentrations both in the short (Boyer et al., 1997) and long term (Yurova et al., 2008). Many processes interact to determine the stream water DOC concentrations and the importance of the processes vary between catchments and throughout the year.

Because of the limited understanding of what controls stream water DOC concentrations during the snowmelt period, the purpose of this study was to improve the understanding of the regulating mechanisms of DOC during the snowmelt period in northern latitude catchments. To do this we used a long-term monitoring record from a small stream in northern Sweden that previously has been used to study the biogeochemical and ecological significance of the spring flood DOC concentrations. From literature studies we could identify three possible explanations for the inter-annual variation: variation in discharge (Köhler et al., 2008), variation in previous DOC export from the catchment (Boyer et al., 1997; Yurova et al., 2008) and the recently discovered effect of winter climate (Haei et al., 2010). Using a statistical approach we investigated which processes were more important in controlling the inter-annaul variation in snowmelt stream DOC concentrations. By removing the hydrological control

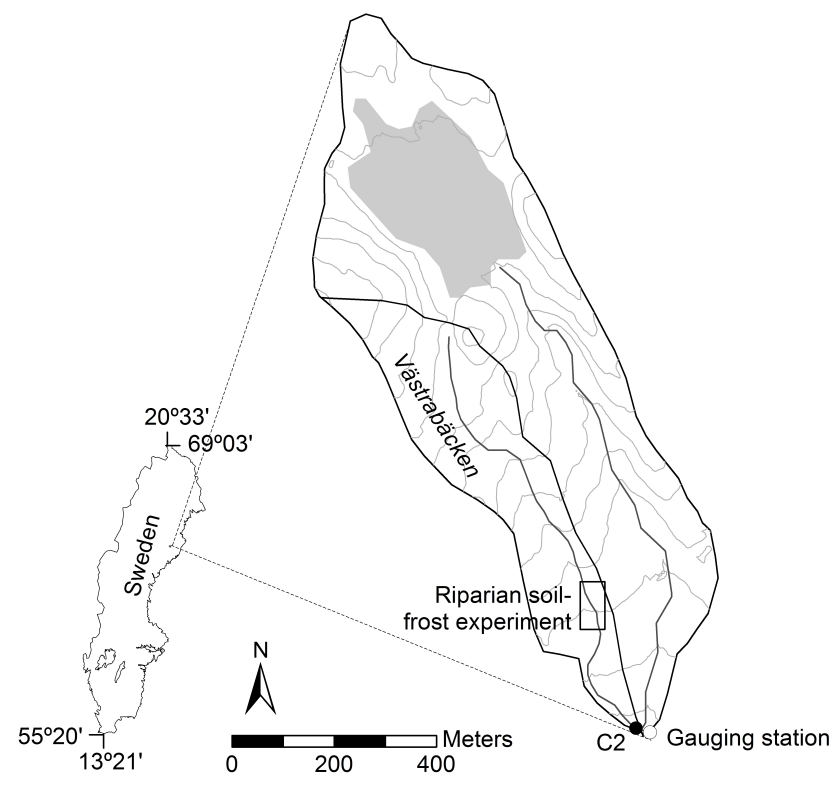

Fig. 1. Map of the study catchment. Sampling site for water chemistry is indicated by a filled circle and discharge measurements by an open circle. Dark grey lines indicate streams, white areas are covered by forests and the gray area indicates mire. Light grey lines indicate the topography using a $5 \mathrm{~m}$ contour interval.

on DOC concentrations, using a stream DOC concentration model that separates the effect of discharge from other factors (Seibert et al., 2009), we calculated the inter-annual variations in soil water DOC during snowmelt caused by other environmental factors. These factors were then used to test what factors could explain the residual DOC concentrations.

\section{Material and method}

\subsection{Study catchment and sampling}

The study catchment was selected because of the availability of a long time-series of stream chemistry, discharge records, meteorological and records of soil physical parameters. The data were collected during 15 years, between 1993 and 2007. The study catchment, Västrabäcken (C2) (Fig. 1), is a 12 ha subcatchment of the Nyänget (Svartberget) catchment (gauging station in Fig. 1). The study catchment is entirely covered by forest, dominated by Norway spruce (Picea abies). The catchments are included in the interdisciplinary Krycklan Catchment Study (KCS) at Vindeln Experimental Forests $\left(64^{\circ}, 14^{\prime} \mathrm{N}, 19^{\circ} 46^{\prime} \mathrm{E}\right)$ in northern Sweden (Buffam et al., 2007). The major soil type is a typical podzolic soil with a 10 to $15 \mathrm{~cm}$ organic layer overlying the mineral soil which is a glacial till. Along the stream there is a riparian zone with organic riparian peat formation. 
Winter climate data were recorded at the nearby Svartberget Research Station, following the standards of the Swedish Meteorological and Hydrological Institute (SMHI). The meteorological station is situated $1.2 \mathrm{~km}$ southwest of Västrabäcken, C2. We give average as well as minimum and maximum values for the years 1993 to 2007 in our short description of the climate conditions in the watershed. The climate was characterized by long winters (winter starts when mean air temperature falls below $0^{\circ} \mathrm{C}$ for three consecutive days and ends when mean air temperature rises above $0{ }^{\circ} \mathrm{C}$ for three consecutive days), on average 165 (133-195) days. The mean annual temperature was $+2.2(1.2-3.1)^{\circ} \mathrm{C}$ and the January temperature was $-8.5(-5.8--13.5)^{\circ} \mathrm{C}$, with the lowest recorded daily temperature at $-30.6^{\circ} \mathrm{C}$. The mean annual precipitation was $620(446-827) \mathrm{mm}$ with an average runoff of $309(128-576) \mathrm{mm}$. The snow-cover generally formed sometime in November (14 October-13 December) and usually ended in the beginning of May (13 April-16 May). The maximum snow depth was on average 77 (55$98) \mathrm{cm}$ and maximum soil frost was on average 18 (2.5-79) $\mathrm{cm}$. The soil frost duration at $5 \mathrm{~cm}$ soil depth and at $10 \mathrm{~cm}$ depth was 121 (12-188) days and $81(0-167)$ days, respectively.

Discharge has been calculated using established rating curves and water level measurements, which has been recorded hourly and then aggregated to daily values. The measurements were conducted just downstream from the study catchment, where a $90^{\circ} \mathrm{V}$-notch weir was located inside a heated housing that prevented ice formation and enabled measurements throughout the whole year. Assuming that the specific discharge was the same throughout the whole catchment ( $47 \mathrm{ha}$ ), the discharge was calculated for the stream water sampling site C2 - Västrabäcken (12 ha) (Fig. 1).

The stream water was collected as grab samples. Before 2002, samples were collected weekly with more intensive sampling during the snowmelt periods. After 2002, samples were collected monthly during base-flow prior to the onset of the snowmelt, and then every second to third day during the spring until the discharge receded to levels close to base-flow. The stream water samples were frozen immediately after collection. TOC analyses were carried out using a Dohrmann Carbon Analyzer before 1995; after that samples were analyzed using a Shimadzu TOC-5000. Linear interpolation was applied to obtain daily values.

Climate data was measured in an open field according to the Swedish standard. The numbers may therefore show an offset to that of the catchment because of the effect of the forest cover. Given the fact that the offset should be systematic for all years, the climate data are still valid in the context of inter-annual variations. The discharge data may also differ at our forested site $\mathrm{C} 2$, compared to what we measure just below the stream junction due to the effect of the wetland (wetland coverage of the whole 47 ha catchment is $16 \%)$. However, the inter-annual variations are greater than the variation between the wetland and the forest (Laudon et al., 2004b) and the use of specific discharge to calculate discharge is adequate for this study.

\subsection{Effect of discharge on stream DOC concentrations}

The relationship between discharge and concentrations was explored using Log-Log relationships (Godsey et al., 2009; Clow and Mast, 2010). We plotted the regression between DOC concentrations in the study stream versus the instantaneous discharge on logarithmic scales (Fig. 3; n=71) and compared the slope of the regression to the reference slopes. On a log-log-scale a slope of -1 means simple dilution and a slope of 0 means that the catchment shows a chemostatic behavior (Godsey et al., 2009; Clow and Mast, 2010). The analysis was conducted on both annual and monthly basis. To test if the Log-Log slope differed significantly from zero, the t-ratio was calculated. According to Helsel and Hirsch (2002), a t-ratio above 2 indicates a significant difference from a slope of zero (if $\alpha=0.05$ and $n>30$ ). The t-ratio was calculated as:

$t-$ ratio $=\frac{b_{1}}{\frac{\operatorname{RMSE}_{S S_{x}}}{S S}}$

Where $b_{1}=$ slope of the regression, RMSE $=$ Root Mean Square Error and $S S_{x}=$ Sums of Squares $x$.

\subsection{What controls stream DOC concentrations during snowmelt?}

Several variables were collected as different measures of the inter-annual variation in DOC during snowmelt. In addition to DOC export ( $\left.\mathrm{DOC}_{\mathrm{EXP}}\right)$ during the snowmelt period, three measures of DOC concentrations during snowmelt were collected: the average DOC concentration during snowmelt

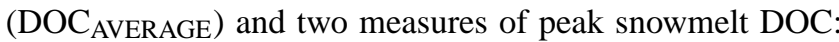
1) DOC concentration during maximum discharge, "flood DOC" $\left(\mathrm{DOC}_{\mathrm{F}}\right)$ and 2) The maximum concentration during snowmelt, "max DOC" $\left(\mathrm{DOC}_{\mathrm{M}}\right)$. $\mathrm{DOC}_{\mathrm{M}}$ occurred on average eight days before the peak in discharge. We also collected data on the inter-annual variation in the slope of the Log DOC-Log Q relationships over the entire snowmelt period.

In total 32 variables were collected as predictors $(X)$ for the inter-annual variation in stream DOC concentrations during snowmelt. They were divided into 3 major groups: Snowmelt variables - different measures to categorize the snowmelt; Winter climate variables - Climate data that describe the winter condition in the air and soil; and Antecedent condition variables - Variables describing the summer and autumn prior to the snowmelt. For a complete list of included variables and how they were defined see Table 1. Partial least square analysis (PLS) is an appropriate method for datasets with less observations than variables ( 15 observations versus 37 variables in our case), many of which may covary. In the 
dataset there were $2 \%$ missing values, these were substituted with series mean. SIMCA-P 11.0 statistical package (Umetrics, Sweden, 2005) was used for the PLS analysis. Prior to analysis all variables were checked for normality using one-sample Kolmogorov-Smirnov test in PASW Statistics 18 (SPSS Inc., Chicago, IL, USA, 2009). Some variables were transformed to fit normality and all were scaled and centred using $z$-scores.

To study the inter-annual variation in stream DOC concentrations during snowmelt, several PLS models were constructed, with one or more $Y$ variables (DOC measures) against the $X$ variables (snowmelt, winter climate, antecedent conditions). The initial PLS models included all 32 predictor variables. The models were thereafter refined, based on two criteria: included variables should be significant (using 95\% confidence interval) and variables were excluded until $R^{2} Y$ was maximized. The same method of refining the PLS models was used for all models in this study.

As a complement to the PLS models, which can sometimes be very complex and difficult to interpret, we have also performed multiple linear regression analysis (MLR). When performing the MLR analysis, we only allowed one variable from each group of $X$-varaibles to be included in the final model, since many of the variables within a group covary and covariate variables are not allowed in MLR.

From the above analyses but also previous work in the study catchment, we know that the discharge is a key component for controlling the DOC concentrations (Köhler et al., 2009; Seibert et al., 2009). To take the analysis of our dataset further, we removed the hydrological effect on DOC concentration by applying a conceptual mathematical model of how the riparian zone and the hydrology control the stream water chemistry. The Riparian Profile Flow-Concentration Integration Model (RIM) has been developed in the study stream. RIM is an attempt to mathematically describe the hydrological effects on DOC and is a result of many years of monitoring and process based research on the study catchment. This has resulted in several articles over the years and a development of a mechanistic understanding of the importance of the riparian zone as a source for the stream organic carbon and other chemical parameters, as well as how these elements are transported across the soil/stream interface (Bishop et al., 1995; Laudon et al., 2004b; Klaminder et al., 2006; Cory et al., 2007; Köhler et al., 2009; Seibert et al., 2009; Öquist et al., 2009b). The riparian zone has been identified as the most important source of carbon in the study stream (Bishop et al., 1994; Köhler et al., 2009; Seibert et al., 2009) and in short, DOC concentration in the stream can be modeled based on the groundwater level (Fig. 2, left panel) and a schematic soil DOC gradient in the riparian soil (Fig. 2, right panel). The concentrations in the stream are modeled by multiplying the lateral water flux at a certain depth with the concentration of the soil water at that depth and then integrating over the horizons with lateral flow i.e. the ones below the ground water table. The DOC concentrations in the soil vary
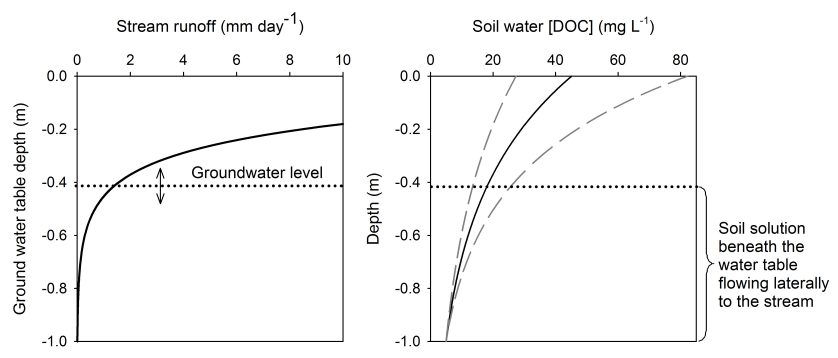

Fig. 2. Schematic view of RIM, modified from Seibert et al. (2009). The left panel shows the relationship between stream runoff and groundwater level. The right panel shows the shape of the soil water DOC concentration profile, grey dashed lines indicate the variation in f-factor (the shape of the profile) in May.

between years and within seasons, these variations are exemplified by grey dashed lines in Fig. 2, right panel. For each depth, the DOC concentrations in the riparian soil solution can be described by an exponential relationship:

$C=c_{0 *} e^{-f * \operatorname{depth}}$

Where $C$ in the concentration at a certain depth, $c_{0}$ is the concentration at depth 0 , and $f$ is a shape factor describing the change in DOC concentrations with depth in the soil water profile. The grey lines (Fig. 2, right panel) show the variation in $f(1.7-2.8)$ that was observed in May according to Seibert et al. (2009). By applying the model using an average $f$ during May (Seibert et al., 2009) (black line, Fig. 2, right panel, $c_{0}=45, f=2.2$ ) we modeled the expected DOC at a certain discharge. The residual DOC, observed minus the modeled, was used as a proxy for the variability in the soil water DOC concentrations that would be needed to correctly simulate stream DOC (Fig. 4). A high (positive) residual DOC indicates that higher concentrations are measured in the stream compared to predicted, i.e. that soil water DOC concentrations (inferred from stream DOC) were higher than the average, and vice versa. Partial least square (PLS) analysis (see below) was used to study the residuals.

After removal of the hydrological effect on stream DOC concentrations (using RIM) during snowmelt, we investigated if hydrology still explained part of the residual DOC concentrations or if we had removed the effect of hydrology. This was tested by constructing a PLS model with the residual DOC concentrations as $Y$ and the snowmelt variables (Table 1) as $X$.

The individual PLS models for residual DOC $\mathrm{AVEREGE}_{\text {, }}$ $\mathrm{DOC}_{\mathrm{M}}$ and $\mathrm{DOC}_{\mathrm{F}}$ produced similar results and presenting them separately did not give any additional information. We therefore present them in the same model. The final PLS model presented is a model with the residual DOC concentrations as $Y$ and all variables (Table 1) (except the snowmelt variables, since the effect of discharge was removed) as $X$. The model was refined until only significant variables 
Table 1. Definition of dependent $(Y)$ and predictor variables $(X)$ used in the PLS analyses.

\begin{tabular}{|c|c|}
\hline Snowmelt DOC variables $(Y)$ & Definition \\
\hline DOC $_{\text {AVERAGE }}$ & Average DOC during snowmelt* $\left(\mathrm{mg} \mathrm{L}^{-1}\right)$ \\
\hline $\mathrm{DOC}_{\mathrm{M}}$ & Maximum DOC during snowmelt $\left(\mathrm{mg} \mathrm{L}^{-1}\right)$ \\
\hline $\mathrm{DOC}_{\mathrm{F}}$ & The DOC concentration during the day with maximum discharge $\left(\mathrm{mg} \mathrm{L}^{-1}\right)$ \\
\hline DOC $_{\mathrm{EXP}}$ & The DOC export during snowmelt $(\mathrm{kg})$ \\
\hline Log-Log slope & The slope of the $\log$ DOC-Log $Q$ relationship during snowmelt \\
\hline \multicolumn{2}{|l|}{ Winter climate variables $(X)$} \\
\hline Winter start & $\begin{array}{l}\text { Start date of winter (when mean air temperature falls below } 0^{\circ} \mathrm{C} \text { for three consecutive days) } \\
\text { (Julian date) }\end{array}$ \\
\hline Winter end & $\begin{array}{l}\text { End date of winter (when mean air temperature falls above } 0^{\circ} \mathrm{C} \text { for three consecutive days) } \\
\text { (Julian date) }\end{array}$ \\
\hline Winter dur. & Duration of winter (Number of days from start to end) \\
\hline Winter days $<0^{\circ} \mathrm{C}$ & Number of days with below-zero air temperature during winter (days) \\
\hline Winter days $>0{ }^{\circ} \mathrm{C}$ & Number of days with above-zero air temperature during winter (days) \\
\hline Air temp. sum & Accumulated daily air temperatures during winter (positively transformed) $\left({ }^{\circ} \mathrm{C}\right)$ \\
\hline Soil temp. sum & $\begin{array}{l}\text { Accumulated hourly recorded soil temperature at } 10 \mathrm{~cm} \text { depth during winter (positively } \\
\text { transformed) }\left({ }^{\circ} \mathrm{C}\right)\end{array}$ \\
\hline Snow depth & Maximum snow depth $(\mathrm{cm})$ \\
\hline Start snow & Start date of permanent snow-cover (Julian date) \\
\hline End snow & End date of permanent snow-cover (Julian date) \\
\hline Snow dur. & Duration of snow-cover (days) \\
\hline Frost depth & Maximum soil frost depth $(\mathrm{cm})$ \\
\hline Soil frost thaw & Start date of soil frost thaw, i.e. when liquid water was found in the soil (Julian date) \\
\hline \multicolumn{2}{|c|}{ Previous hydrology and DOC export $(X)$} \\
\hline DOC baseflow & Mean [DOC] during winter baseflow (January-March) \\
\hline DOC exp. winter & Total DOC export during winter $(\mathrm{kg})$ \\
\hline$Q \mathrm{Jan}$ & Specific discharge on Jan $1^{\text {st }}\left(\mathrm{mm} \mathrm{day}^{-1}\right)$ \\
\hline$Q$ month prior & Specific discharge one month prior to the start of snowmelt $\left(\mathrm{mm} \mathrm{day}^{-1}\right)$ \\
\hline$Q$ winter & Total discharge during winter $(\mathrm{mm})$ \\
\hline$Q$ summer/fall & Total discharge from the end of the previous snowmelt to the start of winter (mm) \\
\hline DOC exp summer/fall & Total DOC export from the end of the previous snowmelt to the start of the winter $(\mathrm{kg})$ \\
\hline DOC Jan & {$[\mathrm{DOC}]$ on January $1^{s t}\left(\mathrm{mg} \mathrm{L}^{-1}\right)$} \\
\hline \multicolumn{2}{|l|}{ Snowmelt variables $(X)$} \\
\hline Start snowmelt & Start date of snowmelt, defined as when discharge $>1 \mathrm{~mm}$ day $^{-1}$ (Julian date) \\
\hline Rising limb dur. & Duration of the snowmelt rising limb (days) \\
\hline Start snowmelt to $\mathrm{DOC}_{\mathrm{M}}$ & Number of days from start date of snowmelt till the date of $\mathrm{DOC}_{M}$ (days) \\
\hline Days $Q>3 \mathrm{~mm}$ & Number of days with specific discharge $>3 \mathrm{~mm} \mathrm{day}^{-1}$ (days) \\
\hline Snowmelt dur. & Number of days with specific discharge $>1 \mathrm{~mm}$ day $^{-1}$ (days) \\
\hline$Q \max$ & Maximum specific discharge during snowmelt $\left(\mathrm{mm} \mathrm{day}^{-1}\right)$ \\
\hline$Q$ tot & Total discharge during snowmelt $(\mathrm{mm})$ \\
\hline$Q_{\mathrm{M}}$ & Discharge on the day of maximum [DOC] \\
\hline Rising limb $Q$ & Discharge from the start of snowmelt until the peak-flow (mm) \\
\hline Date $\mathrm{DOC}_{\mathrm{M}}$ & Date of $\left[\mathrm{DOC}_{\mathrm{M}}\right]$ (Julian date) \\
\hline Date $\mathrm{DOC}_{\mathrm{F}}$ & Date of $\left[\mathrm{DOC}_{\mathrm{F}}\right]$ (Julian date) \\
\hline
\end{tabular}

${ }^{*}$ The snowmelt period was defined as when discharge $>1 \mathrm{~mm} \mathrm{day}^{-1}$, some years the discharge at the end of the snowmelt remains $>1$ mm day ${ }^{-1}$ due to rains, on those years the snowmelt was set to end when there was no snow left in the catchment.

(95\% confidence interval) remained. Because only two variables were significant at the $95 \%$ level, we also investigated the variables that were significant at $90 \%$ significance level (Fig. 6).

\section{Results}

The discharge in May varied more (with a factor of 49) compared to the DOC concentrations which varied with a factor of 2.5 (Fig. 3). The Log-Log relationship between DOC 

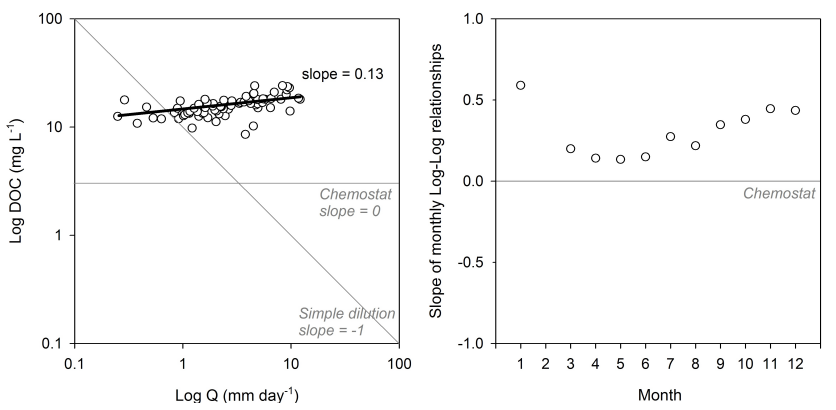

Fig. 3. Scatter plot of concentration - discharge relationship in May during 15 years in Västrabäcken, plotted on a Log-Log scale (Left panel). Reference lines indicate the slopes 0 and -1 , which correspond to chemostatic behavior and simple dilution, respectively. The right panel displays the monthly slopes of the Log-Log concentration - discharge relationships. All (but February) were significant on the 0.05 level.

and $\mathrm{Q}$ indicate how discharge and concentrations interact (Fig. 3, left panel) $\left(y=0.13 x+1.14, R^{2}=0.39, p<0.001\right.$, $n=71$ ). For the month of May the slope was 0.13 (standard error $=0.023$ ) which was significantly different from zero as indicated by the $t$-ratio (Eq. 1). This means that the stream DOC concentrations during snowmelt increased with discharge more than expected, given a chemostatic behavior of the catchment. The annual slope was even higher: 0.22 (standard error $=0.012$ ) for the annual relationship $(y=0.22 x+$ $\left.1.19, R^{2}=0.41, p<0.001, n=469\right)$. The lowest slopes were found during spring and the highest in late autumn and mid winter (Fig. 3, right panel).

There were also large inter-annual variations in DOC concentrations during snowmelt. DOC AVERAGE, $_{\text {DOC }}$ and $\mathrm{DOC}_{\mathrm{F}}$ ranged between 11.7-26.1, 17.7-30.1 and 15.6$29.3 \mathrm{mg} \mathrm{L}^{-1}$, respectively, over the 15 years, hence varying with a factor of 2.2, 1.7 and 1.9, respectively (Fig. 4). During some years the discharge explained almost all the variation in the spring flood DOC concentrations (RMSE $=4.34 \mathrm{mg} \mathrm{L}^{-1}$ for the RIM-modeled values for May), but in other years, other factors were clearly also important as indicated by a large residual DOC after applying RIM (Fig. 4).

The PLS model showed that the DOC export was related both to the amount of the exported water and the concentrations during snowmelt. A complimentary MLR analysis showed that $79 \%$ of the variance was explained by the total amount of water draining during snowmelt (Q tot) and 15\% of the variance in the DOC concentrations during maximum discharge $\left(\mathrm{DOC}_{\mathrm{F}}\right)\left(R^{2}=0.94, p<0.000\right)$.

The DOC concentrations during snowmelt $\left(\mathrm{DOC}_{\mathrm{M}}, \mathrm{DOC}_{\mathrm{F}}\right.$ and DOC $_{\text {AVERAGE }}$ ) covaried and were explained with similar variables. When studying the $Y$ values individually, the explaining variables could somewhat vary; for example, $\mathrm{DOC}_{\mathrm{F}}$ and $\mathrm{DOC}_{\mathrm{AVERAGE}}$ were more correlated to snowmelt variables while $\mathrm{DOC}_{M}$ was more correlated to winter climate variables. Variables from all three groups of pre-
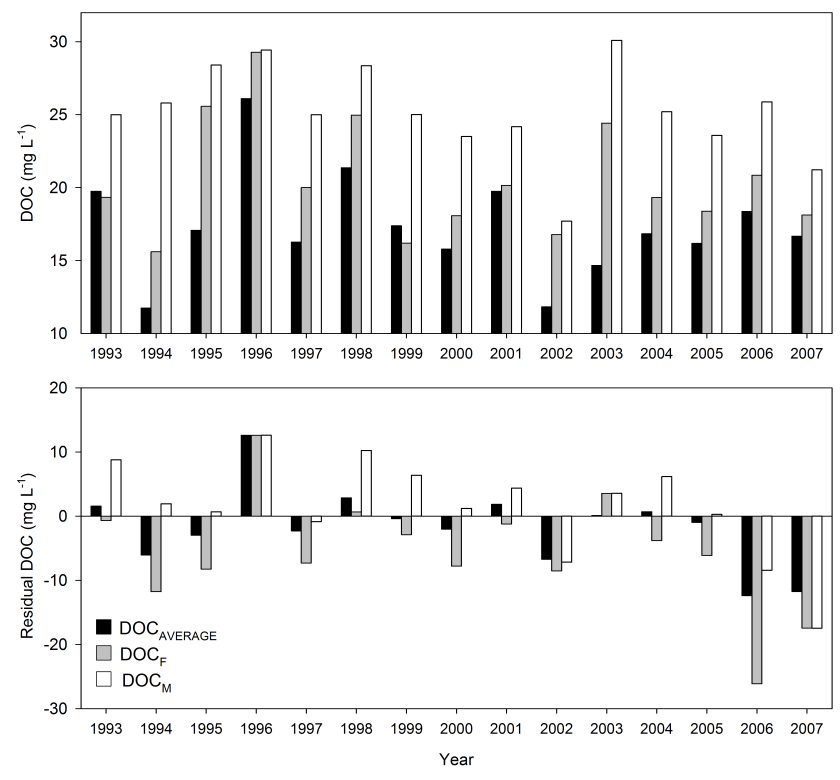

Fig. 4. The top panel show the inter-annual variation in

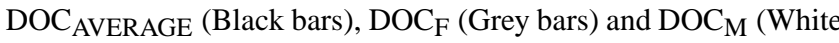

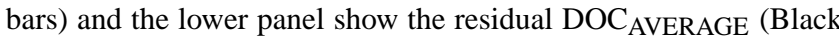
bars), $\mathrm{DOC}_{\mathrm{F}}$ (Grey bars) and $\mathrm{DOC}_{\mathrm{M}}$ (White bars) after subtraction with the RIM modelled values. A positive residual DOC indicates high soil water DOC during spring inferred from stream DOC concentrations, and vice versa.

dictors (snowmelt, winter climate, antecedent conditions) were significant in explaining the inter-annual variation in stream concentrations during snowmelt $\left(\mathrm{DOC}_{\mathrm{M}}, \mathrm{DOC}_{\mathrm{F}}\right.$ and DOC $_{\text {AVERAGE }}$ ) (Fig. 5, left panel). The most important variable was the duration of the rising limb of the snowmelt hydrograph (Rising limb dur.), indicating that a short and intense snowmelt yielded higher DOC concentrations in the stream. Discharge and DOC export during the antecedent summer and fall related negatively to spring flood DOC concentrations. There were three winter climate variables that related positively to the spring flood DOC concentrations (winter duration, number of days during winter with temperatures below zero, and the end of winter). These three variables covaried and should not be interpreted individually but rather as different measures of a long winter. A principal component analyses (PCA) of the entire dataset indicated no close correlation between rising limb duration and winter duration. This ensured that the relationship we found with long winter was not just an artifact, since a snowmelt following a long winter might eventually be more rapid and intense.

There was an inter-annual variability in the Log-Log slope during snowmelt $(0.10-0.44)$. The slope was negatively related to the number of days from the start of snowmelt to the date of $\mathrm{DOC}_{\mathrm{M}}$ and also to the duration of the rising limb (Fig. 5, right panel). That means that the slope was steeper, i.e. the catchment exported higher concentrations per unit of discharge, in years when the snowmelt episode was short and 

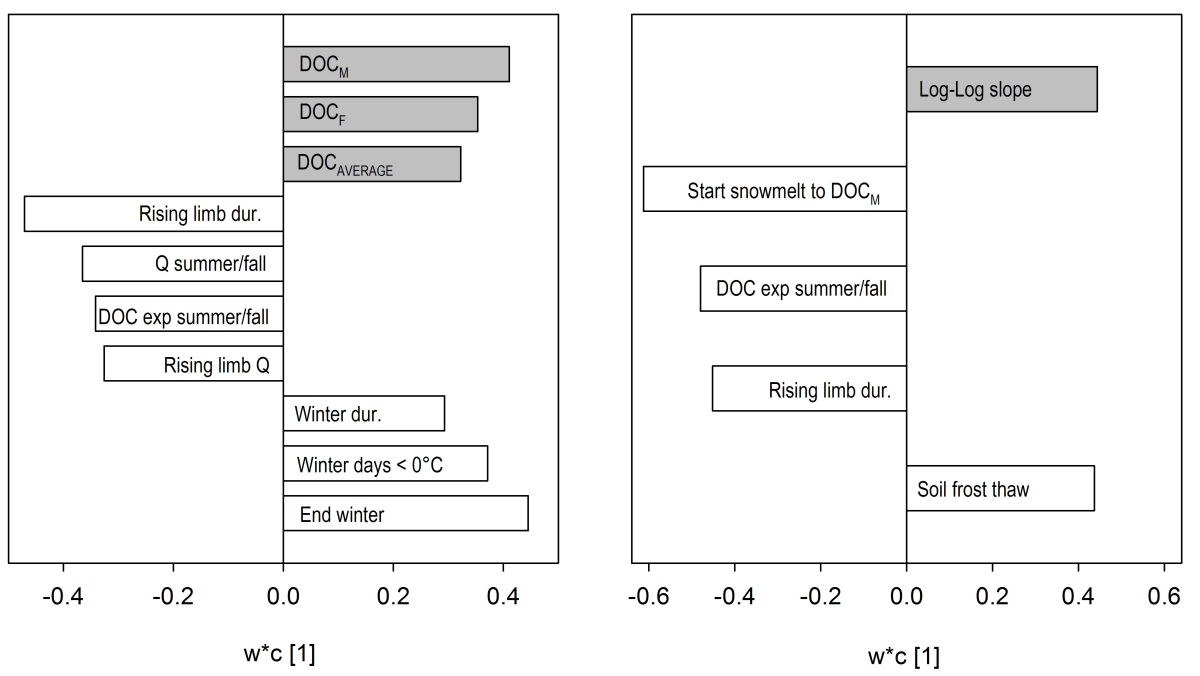

Fig. 5. PLS weight plot, showing that high $\mathrm{DOC}_{\mathrm{M}}, \mathrm{DOC}_{F}$ and $\mathrm{DOC}_{\mathrm{AVER}} \mathrm{AGE}$ correlate positively to long winters and negatively to previous export during summer/fall and low intensity snowmelts with much water $\left(R^{2} X=0.46, R^{2} Y=0.41, Q^{2}=0.29\right)$ (Left panel). PLS weight plot, showing that high Log-Log slope correlates positively to delayed soil frost thaw and negatively to low intensity snowmelts and high previous export $\left(R^{2} X=0.50, R^{2} Y=0.38, Q^{2}=0.21\right)$ (Right panel). $Y$ variables are marked in grey and significant (95\% confidence level) $X$ variables in white.

intense. The slope was negatively related to the DOC export during the antecedent summer and fall and positively related to a delayed soil frost thaw, which in turn is correlated to a long winter. The results from the two analyses, shown in the left and right panels of Fig. 5, showed the same pattern; High DOC concentrations during spring flood were found in years with a short snowmelt episode, long antecedent winter, and low previous export.

After applying RIM, no significant PLS model could be constructed between residual DOC and the snowmelt variables, which supported the notion that we effectively removed the effect of discharge. The refined PLS model with the residual DOC concentrations as $Y$ and all $X$ variables (Table 1) (now excluding the snowmelt variables) that was refined at $95 \%$ significance level showed that the residual DOC concentrations were positively correlated to the number of days below zero ${ }^{\circ} \mathrm{C}$ during winter and the duration of winter $\left(R^{2} X=0.96, R^{2} Y=0.30, Q^{2}=0.23\right)$. Since only two variables were significant on the $95 \%$ level, we also investigated the significant variables using $90 \%$ confidence interval (Fig. 6, left panel) $\left(R^{2} X=0.54, R^{2} Y=0.38, Q^{2}=0.23\right)$. The new model included four more variables; two indicating that long winters enhanced DOC during snowmelt, and two indicating that a wet winter with high antecedent DOC export decreased the DOC concentrations. It should be noted that the models were not suited for predictions given the low $\mathrm{Q}^{2}$ value. To illustrate the relationship between spring flood DOC concentrations and winter climate we have plotted the relationship between the two variables that had the highest weights in the PLS model (Fig. 6, right panel).

\section{Discussion}

We found a large inter-annual variation in the spring flood DOC concentrations (Fig. 4). DOC exports from a catchment are important as a carbon source for the stream and downstream lake/sea heterotrophic community, and thus affect the carbon balance (Cole et al., 2007; Ågren et al., 2008; Nilsson et al., 2008). The organic carbon also controls much of the export of metals and organic pollutants (Bergknut et al., 2010). Here we found that even though most of the variance in the DOC exports during snowmelt was controlled by the amount of water draining, the DOC concentration during peak snowmelt $\left(\mathrm{DOC}_{\mathrm{F}}\right)$ still explained $15 \%$ of the interannual variability in DOC exports. The DOC concentrations have also been found to be important for stream $\mathrm{pH}$ during snowmelt (Laudon et al., 2000). The annual minimum $\mathrm{pH}$ in this stream was also found to be significantly correlated to maximum DOC concentration (DOC $\mathrm{M}$ ) (MLR: $R^{2}=0.30$, $p=0.04$, not shown). During snowmelt the acid neutralizing capacity (ANC) is diluted with low base cation (BC) melt water and the increasing concentrations of organic acids (DOC) along with anthropogenically derived acids cause $\mathrm{pH}$ to drop, and a pH drop with 1-2 pH units are not unusual during snowmelt. This short but extreme period, with respect to $\mathrm{pH}$, controls the distribution of acid sensitive aquatic species (Holmgren and Buffam, 2005; Fölster et al., 2007; Laudon and Buffam, 2008). For example, in the study stream, the survival of brown trout was strongly correlated to stream $\mathrm{pH}$ (Serrano et al. 2008). Stream DOC concentration during the snowmelt period is hence important for the stream ecology as a partial control for the DOC exports, but also directly 

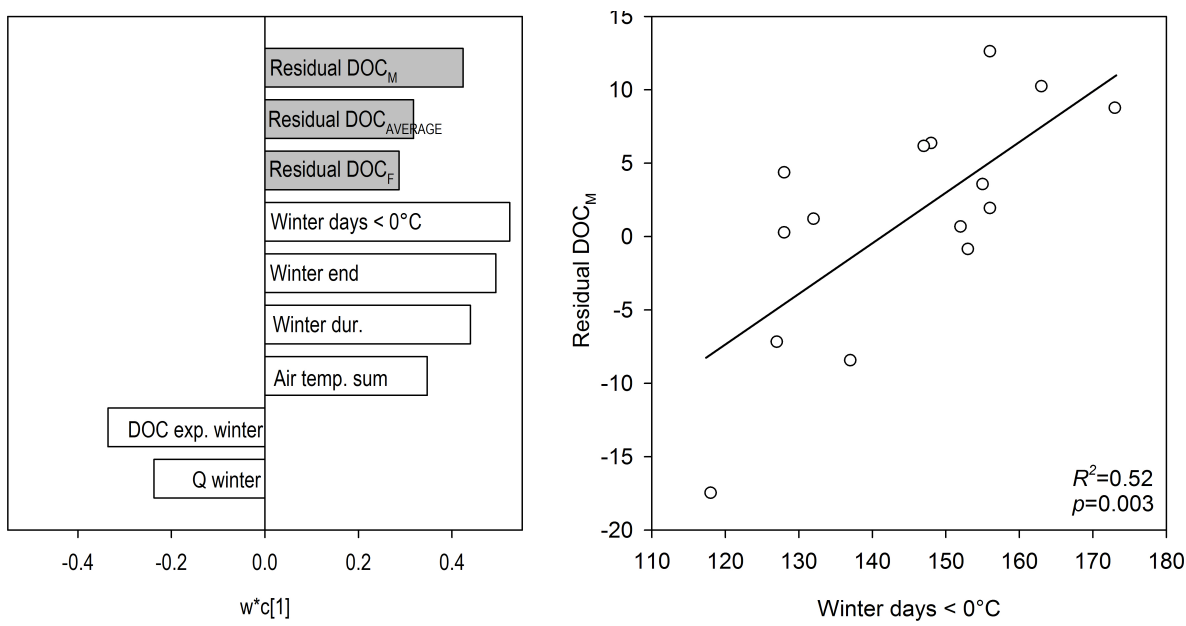

Fig. 6. Left panel: PLS weight plot $\left(R^{2} X=0.54, R^{2} Y=0.38, Q^{2}=0.23\right)$, showing that high soil water DOC concentrations, inferred from stream DOC, (indicated by the Residual DOC concentrations) correlate positively to long cold winters and negatively to a high previous DOC export during winter. This means higher soil water DOC concentrations after long winters with low export. The $Y$ variables are marked in grey and the six significant $\left(90 \%\right.$ significance level) $X$ variables in white. Right panel: Linear regression between Residual $\mathrm{DOC}_{\mathrm{M}}$ and Winter days $<0^{\circ} \mathrm{C}$ (the variables with the highest weights), illustrating the relationship between long severe winters and spring flood DOC concentrations.

affecting the conditions in the stream and survival of acid sensitive species.

The Västrabäcken catchment does not show a true chemostatic behavior (Godsey et al., 2009; Clow and Mast, 2010). If that would have been the case, the concentration would be independent of stream discharge. The positive annual slope of the Log-Log relationship indicates that the concentrations increase with discharge. This is in line with the exponential increase in DOC concentrations upward in the soil profile that gives higher concentrations during high flows, as described in RIM (Seibert et al., 2009). The monthly analysis revealed that the slope of the regression increased from snowmelt to January, indicating that the soil water DOC concentrations (inferred from stream DOC) continue to increase during growing season and into winter, and then decreased at the onset of snowmelt. An increase over the growing season has also been found in other studies (Cronan and Aiken, 1985; McDowell and Likens, 1988; Kalbitz et al., 2000). Here we show that this increase in soil solution DOC concentrations is likely to continue during winter (Fig. 3).

By using data from the intensively monitored Västrabäcken catchment, coupled with experiments in the riparian zone previously presented by Haei et al. (2010), we could elucidate the processes that control the inter-annual variations in DOC concentration during the spring. As mentioned in the methods section we have performed many analyses to test what controls stream water DOC concentrations during the spring. Despite some differences in the results of the different PLS models, we found a consistent pattern that is illustrated in Fig. 5. The DOC concentrations during snowmelt were only weakly related to the amount of discharge during snowmelt, but more to the intensity of the snowmelt. The highest DOC concentrations were found during years when the snowmelt rising limb was short. The concentrations were also higher following long winters when previous export during the antecedent summer and fall had been low. The PLS analysis of the inter-annual variation in the slope of the Log-Log relationship during snowmelt (Fig. 5, Right panel) showed similar explanatory variables with the DOC concentrations (Fig. 5, left panel). The catchment exported higher DOC concentrations per unit of discharge in years with delayed soil frost thaw (another measure of long winters), with a short and intense snowmelt and when the antecedent DOC export had been low.

The DOC concentrations in the soil water (that will enter the stream by lateral flow) are controlled by several mechanisms. In short, it is a combination of many competing processes and is the net effect of the production rate and the removal rate of DOC. Soil water DOC is produced in the soil by soil organic matter breakdown (Moore et al., 2008). The production rate of DOC has been found to be controlled by high microbial activity, high fungal abundance and seasonality of plant growth. Concentration of anions and cations in the soil are also important (Kalbitz et al., 2000). High moisture and temperature promote the production of DOC (Christ and David, 1996). The removal rate is regulated by the adsorption to minerals (Guggenberger and Kaiser, 2003), mineralization to $\mathrm{CO}_{2}$ (Bengtson and Bengtsson, 2007) and the DOC export from the catchments.

A high antecedent export of DOC from the catchment will decrease the DOC concentrations (Fig. 5) unless the production rate can compensate for the loss of carbon. The 
concentrations will be depressed until more of the soil carbon has been released as DOC and is readily available for leaching. We found that this "memory effect" of the catchment was prolonged and the effect of a high export during previous summer and autumn was still detectable during the following snowmelt (Fig. 5). This is in line with the study by Yurova et al. (2008), from a neighboring mire catchment, who also found a "memory effect" where the amount of sorbed, potentially soluble organic carbon in a year affected the DOC concentrations and fluxes the following year.

Based on the positive relationship between Log DOC-Log discharge (Fig. 3), we would expect higher concentrations in years with high discharge. However, the spring flood DOC concentrations were more highly correlated to duration of the snowmelt rising limb than to the amount of water (Fig. 5). What could explain this pattern? The same process that we find in the relationship between snowmelt DOC and antecedent summer and fall DOC export is likely also active on a much smaller scale. During snowmelt, when the water table rises, it is likely that the initial DOC concentrations draining from a certain soil layer is higher in the beginning unless the release of new DOC to the soil water can keep up with the export from that soil layer. When the discharge increases further, new carbon sources are activated because more soil horizons become hydrologically connected when the water table rises further. This results in an increase in DOC concentrations in the stream. However, there might still have been a decrease in the concentrations draining the initial soil layer. This could explain why a short and intense snowmelt gave higher stream DOC concentrations. If all soil horizons drain more or less simultaneously, all horizons would export the "highest initial concentrations". In contrast, during a year when the snowmelt was prolonged, one soil layer at the time might have been "flushed" (Boyer et al., 1997) from easily exported DOC, resulting in slightly lower stream DOC concentrations during snowmelt.

This study also identifies another important controlling mechanism: winter climate. This was an explanatory variable in the initial PLS analysis and after subtracting the hydrological effect on DOC using RIM, winter climate variables were the only variables that explained the inter-annual variation in the inferred soil water concentrations (at the 95\% significance level). The four winter climate variables that were significant predictors for residual DOC concentrations at the $90 \%$ level (Fig. 6) are correlated and could all be seen as measures of a long, and perhaps cold, winter. It is worth noting that the number of days above zero degrees during winter could not explain any variability in spring time DOC, it was the number of days below zero that was the best predictor. The inferred soil water DOC concentrations during snowmelt related negatively to the export of DOC during antecedent winter, which is in line with the notion that DOC export creates a "memory effect" in both the long-term and short-term.
That a long winter enhanced snowmelt soil water concentrations was further corroborated by a field-scale soil frost manipulation experiment in the riparian zone of the study stream (Haei et al., 2010). During normal winters (72 days of soil frost) the DOC concentrations at $10 \mathrm{~cm}$ depth were on average about $10 \mathrm{mg} \mathrm{L}^{-1}$ higher compared to the no soil frost scenario ( 0 days with soil frost). When the soil frost duration was extended to 144 days, by removing the snow, the DOC concentrations increased markedly with another $50 \mathrm{mg} \mathrm{L}^{-1}$ compared to the normal winter. The span in DOC concentrations in the soil frost manipulations ranged $60 \mathrm{mg} \mathrm{L}^{-1}$, which can be compared to the inter-annual variation in calculated residual DOC concentrations which ranged $25-40 \mathrm{mg} \mathrm{L}^{-1}$ (Fig. 4). We expected a higher effect of the manipulation experiment because the soil frost manipulation was stronger than the natural variability in the winter climate.

The increase in soil water DOC concentrations following a long winter can be a result of an increased production rate of DOC or that more DOC is conserved in the soil. By "conservation" we mean that the carbon that was produced during the vegetation period is mineralized into $\mathrm{CO}_{2}$ at lower rates in subzero temperatures during winter (Panikova et al., 2006; Öquist et al., 2009a). An increased winter production of DOC might be explained by both physical and biological processes. Physically, the freezing temperature itself may cause freeze damage to the cells (Soulides and Allison, 1961). Disruption of the soil caused by frost heaving, formation of ice lenses and/or capillary water movement may damage fine roots (Tierney et al., 2001) or ectomycorrhizal fungi and free living microorganisms (Giesler et al., 2007), or make previously sorbed organic matter more available for leaching (Kalbitz et al., 2000; Yurova et al., 2008). A biological process that might be important for the DOC production during winter is the adaption of organisms to cold temperatures. Elevated levels of carbohydrates have been suggested to function as osmoregulators for freeze protection in trees (Scott-Denton et al., 2006; Wong et al., 2009). The microbial community can also adapt to sub-zero temperatures (Rilfors and Lindblom, 2002) or shift in species composition towards fast growing, cold-adapted microbes that can grow in low temperatures (down to $-5^{\circ} \mathrm{C}$ ) (Lipson and Schmidt, 2004). The cold-adapted microbial biomass reaches its maximum levels in late winter (Schmidt and Lipson, 2004) and this might lead to an increased DOC production during a long winter. From this study we cannot identify the exact processes behind the increasing DOC concentrations following a long winter, but a combination of the above processes seems plausible.

Based on the weight of the variables in the PLS models (Fig. 5), we showed that hydrology had a first order control on the inter-annual variation in DOC concentrations in the streams during snowmelt. We also demonstrated that the length of the winter was more important than the memory effect of previous export for the inferred soil water DOC concentrations during snowmelt (based on the weight of the 
variables and the significance level of the variables (Fig. 6). The soil frost experiment from Haei et al. (2010) corroborates this result and shows that long winters i.e. long soil frost duration, increased the soil water DOC concentrations.

The results of the 15 year stream record in this study were similar to the results in the study by Haei et al. (2010). Therefore we highlight the differences between the two studies. The studies were carried out in two different types of streams; this study investigated an entirely forest-covered subcatchment of the Haei study catchment (which also includes the influence of a mire). The Haei study focused only on peak DOC concentration $\left(\mathrm{DOC}_{\mathrm{M}}\right.$ ) while we included four more response variables in this study; the concentration during maximum discharge $\left(\mathrm{DOC}_{\mathrm{F}}\right)$ and three variables that integrate DOC over the whole spring flood period (DOC $\mathrm{EXP}_{\text {, }}$

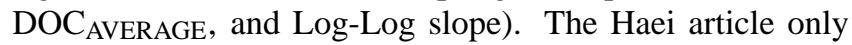
discussed the effect of winter climate (even though the effect of snowmelt intensity and memory effect was found in the result), while in this work we discuss all processes controlling the DOC concentrations during spring flood and investigated the relative importance of the processes. By including more variables and expanding the process discussion, this work is a clear step forward in understanding the inter-annual control of DOC concentrations during the snowmelt period in the seasonally snow-covered forested study catchment.

Increasing temperature has been suggested as one of the explanations for the increasing long-term trends in DOC found in parts of North America and Europe (Sarkkola et al., 2009). Many studies suggest that climate change scenarios leading to higher temperature and precipitation will increase the amount of DOC in streams, especially during summer and autumn (Hongve et al., 2004; Futter and de Wit, 2008; Köhler et al., 2009; Erlandsson et al., 2008). These studies are either considering the growing season only or represent more southerly areas where snowmelt is not of such fundamental importance for the annual water and carbon flux. However, our study indicates that winter climate can be of fundamental importance for controlling spring flood DOC concentrations in seasonally snow covered boreal systems.

In a future climate the DOC exports during snowmelt will probably be reduced because the amount of water, which we showed controlled most of the variability in the DOC exports, is extenuated due to a reduced snowpack. How future climate will affect stream water DOC concentrations in this catchment depends on the interacting effects of winter temperatures as well as the timing, duration and depth of snow accumulation. Models predict a change in soil temperatures in response to a change in the snow cover, however, models do not agree. Mellander et al. (2007) predicted a warming of the soils during winter, but, a decrease in the snow-cover might also lead to colder soils (Groffman et al., 2001), especially during a transition period, as a result of reduced depth of the insulating snow-cover (Hardy et al., 2001; Isard et al., 2007). Precipitation is also predicted to increase in the future. As wet soils require longer time to freeze because of more latent heat, future winter soils may become warmer instead of colder, however the moisture will also delay warming in spring. The increased soil frost due to the removal of snow in the soil frost manipulation experiment could possibly suggest an increasing DOC concentration in a future climate. At the same time our PLS analysis of the stream record suggests that a shorter winter with more days above zero degrees would decrease the DOC concentrations. While these results are difficult to directly translate to a future climate change prediction, they highlight the importance of winter climate conditions for controlling spring flood DOC concentrations in northern boreal systems.

Acknowledgements. The financial support for this work has over the years been provided by Swedish Science Foundation, Formas, Swedish EPA, SLU-Foma and Future Forest. Numerous people have been involved in the sampling and lab work of which we especially thank Elon Manfredsson, Hans-Göran Nilsson and Peder Blomkvist.

Edited by: T. J. Battin

\section{References}

Ågren, A., Jansson, M., Ivarsson, H., Bishop, K., and Seibert, J.: Seasonal and runoff-related changes in allochtonous organic carbon concentrations in the River Öre, Northern Sweden, Aquat. Sci., 70, 21-29, 2007.

Ågren, A., Berggren, M., Laudon, H., and Jansson, M.: Terrestrial export of highly bioalvailable carbon from small boreal catchments in spring floods, Freshwater Biol., 53, 964-972, 2008.

Bengtson, P. and Bengtsson, G.: Rapid turnover of DOC in temperate forests accounts for increased $\mathrm{CO}_{2}$ production at elevated temperatures, Ecol. Lett., 10, 783-790, doi:0.1111/j.14610248.2007.01072.x, 2007.

Bergknut, M., Meijer, S., Halsall, C., Ågren, A., Laudon, H., Köhler, S., Jones, K. C., Tysklind, M., and Wiberg, K.: Modelling the fate of hydrophobic organic contaminants in a boreal forest catchment: A cross disciplinary approach to assessing diffuse pollution to surface waters, Environ. Pollut., 158, 29642969, 2010.

Bishop, K., Pettersson, C., Allard, B., and Lee, Y. H.: Identification of the riparian sources of aquatic dissolved organic-carbon, Environ. Int., 20, 11-19, 1994.

Bishop, K., Lee, Y. H., Pettersson, C., and Allard, B.: Terrestrial Sources of Methylmercury in Surface Waters - the Importance of the Riparian Zone on the Svartberget Catchment, Water Air Soil Poll., 80, 435-444, 1995.

Bishop, K., Seibert, J., Köhler, S., and Laudon, H.: Resolving the Double Paradox of rapidly mobilized old water with highly variable responses in runoff chemistry, Hydrol. Process., 18, 185189, 2004.

Bishop, K. H., Grip, H., and O'neill, A.: The Origins of Acid Runoff in a Hillslope During Storm Events, J. Hydrol., 116, 3561, 1990.

Boyer, E. W., Hornberger, G. M., Bencala, K. E., and McKnight, D. M.: Response characteristics of DOC flushing in an alpine catchment, Hydrol. Process., 11, 1635-1647, 1997. 
Buffam, I., Laudon, H., Temnerud, J., Mörth, C.-M., and Bishop, K.: Landscape-scale variability of acidity and dissolved organic carbon during spring flood in a boreal stream network, J. Geophys. Res., 112, G01022, doi:10.1029/2006JG000218, 2007.

Christ, M. J., and David, M. B.: Temperature and moisture effects on the production of dissolved organic carbon in a Spodosol, Soil Biol. Biochem., 28, 1191-1199, 1996.

Christensen, J.H., Hewitson, B., Busuioc, A., Chen, A., Gao, X., Held, I., Jones, R., Kolli, R. K., Kwon, W.-T., Laprise, R., Magaña Rueda, V., Mearns, L., Menéndez, C. G., Räisänen, J., Rinke, A., Sarr, A., and Whetton, P.: Regional Climate Projections. In: Climate Change 2007: The Physical Science Basis. Contribution of Working Group I to the Fourth Assessment Report of the Intergovernmental Panel on Climate Change. Solomon, S., Qin, D., Manning, M., Chen, Z., Marquis, M., Averyt, K. B., Tignor, M., and Miller, H. L. (eds.) Cambridge University Press, Cambridge, United Kingdom and New York, NY, USA, p. 875, 2007.

Clow, D. W., and Mast, M. A.: Mechanisms for chemostatic behavior in catchments: Implications for $\mathrm{CO}_{2}$ consumption by mineral weathering, Chem. Geol., 269, 40-51, 2010.

Cole, J. J., Prairie, Y. T., Caraco, N. F., McDowell, W. H., Tranvik, L. J., Striegl, R. G., Duarte, C. M., Kortelainen, P., Downing, J. A., Middelburg, J. J., and Melack, J.: Plumbing the global carbon cycle: Integrating inland waters into the terrestrial carbon budget, Ecosystems, 10, 171-184, 2007.

Cory, N., Laudon, H., Köhler, S., Seibert, J., and Bishop, K.: Evolution of soil solution aluminum during transport along a forested boreal hillslope, J. Geophys. Res. 112, G03014, doi:10.1029/2006JG000387, 2007.

Cronan, C. S. and Aiken, G. R.: Chemistry and Transport of Soluble Humic Substances in Forested Watersheds of the Adirondack Park, New-York, Geochim. Cosmochim. Ac., 49, 1697-1705, 1985.

Dawson, J. J. C., Soulsby, C., Tetzlaff, D., Hrachowitz, M., Dunn, S. M., and Malcolm, I. A.: Influence of hydrology and seasonality on DOC exports from three contrasting upland catchments, Biogeochemistry, 90, 93-113, 2008.

Duarte, C. M. and Prairie, Y. T.: Prevalence of heterotrophy and atmospheric $\mathrm{CO} 2$ emissions from aquatic ecosystems, Ecosystems, 8, 862-870, 2005.

De Wit, H. A. and Wright, R. F.: Projected Stream Water Fluxes of $\mathrm{NO}_{3}$ and Total Organic Carbon from the Storgama Headwater Catchment, Norway, under Climate Change and Reduced Acid Deposition, Ambio, 37, 56-63, 2008.

Dosskey, M. G. and Bertsch, P. M.: Forest Sources and Pathways of Organic-Matter Transport to a Blackwater Stream - a Hydrologic Approach, Biogeochemistry, 24, 1-19, 1994.

Erlandsson, M., Buffam, I., Fölster, J., Laudon, H., Temnerud, J., Weyhenmeyer, G. A., and Bishop, K.: Thirty-five years of synchrony in the organic matter concentrations of Swedish rivers explained by variation in flow and sulphate, Global Change Biol., 14, 1191-1198, 2008.

Fölster, J., Andrén, C., Bishop, K., Buffam, I., Cory, N., Goedkoop, W., Holmgren, K., Johnson, R., Laudon, H., and Wilander, A.: A novel environmental quality criterion for acidification in Swedish lakes - an application of studies on the relationship between biota and water chemistry, Water Air Soil Poll., 7, 331-338, 2007.

Futter, M. N. and de Wit, H. A.: Testing seasonal and long-term controls of streamwater DOC using empirical and process-based models, Sci. Total Environ., 407, 698-707, 2008.

Futter, M. N., Forsius, M., Holmberg, M., and Starr, M.: A longterm simulation of the effects of acidic deposition and climate change on surface water dissolved organic carbon concentrations in a boreal catchment, Hydrol. Res., 40, 291-305, 2009.

Giesler, R., Högberg, M. N., Strobel, B. W., Richter, A., Nordgren, A., and Högberg, P.: Production of dissolved organic carbon and low-molecular weight organic acids in soil solution driven by recent tree photosynthate, Biogeochemistry, 84, 1-12, 2007.

Godsey, S. E., Kirchner, J. W., and Clow, D. W.: Concentrationdischarge relationships reflect chemostatic characteristics of US catchments, Hydrol. Process., 23, 1844-1864, 2009.

Groffman, P. M., Driscoll, C. T., Fahey, T. J., Hardy, J. P., Fitzhugh, R. D., and Tierney, G. L.: Colder soils in a warmer world: A snow manipulation study in a northern hardwood forest ecosystem, Biogeochemistry, 56, 135-150, doi:10.5194/bg-56-1352001, 2001.

Guggenberger, G. and Kaiser, K.: Dissolved organic matter in soil: challenging the paradigm of sorptive preservation, Geoderma, 113, 293-310, 2003.

Haei, M., Öquist, M. G., Buffam, I., Ågren, A., Blomkvist, P., Bishop, K., Löfvenius, M. O., and Laudon, H.: Cold winter soils enhance dissolved organic carbon concentrations in soil and stream water, Geophys. Res. Lett., 37, L08501, doi:10.1029/2010g1042821, 2010.

Hardy, J. P., Groffman, P. M., Fitzhugh, R. D., Henry, K. S., Welman, A. T., Demers, J. D., Fahey, T. J., Driscoll, C. T., Tierney, G. L., and Nolan, S.: Snow depth manipulation and its influence on soil frost and water dynamics in a northern hardwood forest, Biogeochemistry, 56, 151-174, 2001.

Hinton, M. J., Schiff, S. L., and English, M. C.: Sources and flowpaths of dissolved organic carbon during storms in two forested watersheds of the Precambrian Shield, Biogeochemistry, 41, 175-197, 1998.

Holmgren, K. and Buffam, I.: Critical values of different acidity indices - as shown by fish communities in Swedish lakes, Verh. Internat. Verein. Limnol., 29, 654-660, 2005.

Hongve, D.: Production of dissolved organic carbon in forested catchments, J. Hydrol., 224, 91-99, 1999.

Hongve, D., Riise, G., and Kristiansen, J. F.: Increased colour and organic acid concentrations in Norwegian forest lakes and drinking water - a result of increased precipitation?, Aquat. Sci., 66, 231-238, 2004.

Hornberger, G. M., Bencala, K. E., and McKnight, D. M.: Hydrological Controls on Dissolved Organic-Carbon During Snowmelt in the Snake River near Montezuma, Colorado, Biogeochemistry, 25, 147-165, 1994.

Inamdar, S., Rupp, J., and Mitchell, M.: Differences in Dissolved Organic Carbon and Nitrogen Responses to Storm-Event and Ground-Water Conditions in a Forested, Glaciated Watershed in Western New York, J. Am. Water Resour. Res., 44, 1458-1473, 2008.

Inamdar, S. P., Christopher, S. F., and Mitchell, M. J.: Export mechanisms for dissolved organic carbon and nitrate during summer storm events in a glaciated forested catchment in New York, USA, Hydrol. Process., 18, 2651-2661, 2004.

IPCC: Climate Change 2007: The Physical Science Basis. Contribution of Working Group I to the Fourth Assessment Report 
of the Intergovernmental Panel on Climate Change, edited by: Solomon, S., Qin, D., Manning, M., Chen, Z., Marquis, M., Averyt, K. B., Tignor, M., and Miller, H. L., Cambridge University Press, Cambridge, UK and New York, NY, USA, 996, 2007.

Isard, S. A., Schaetzl, R. J., and Andresen, J. A.: Soils cool as climate warms in the great lakes region: 1951-2000, Ann. Assoc. Am. Geogr., 97, 467-476, 2007.

Jansson, M., Persson, L., De Roos, A. M., Jones, R. I., and Tranvik, L. J.: Terrestrial carbon and intraspecific size-variation shape lake ecosystems, Trends Ecol. Evol., 22, 316-322, 2007.

Kalbitz, K., Solinger, S., Park, J. H., Michalzik, B., and Matzner, E.: Controls on the dynamics of dissolved organic matter in soils: A review, Soil Sci., 165, 277-304, 2000.

Klaminder, J., Bindler, R., Laudon, H., Bishop, K., Emteryd, O., and Renberg, I.: Flux rates of atmospheric lead pollution within soils of a small catchment in northern Sweden and their implications for future stream water quality, Environ. Sci. Technol., 40, 4639-4645, 2006.

Köhler, S. J., Buffam, I., Laudon, H., and Bishop, K.: Climate's control of intra-annual and inter-annual variability of total organic carbon concentration and flux in two contrasting boreal landscape elements, J. Geophys. Res., 113, G03012, doi:10.1029/2007JG000629, 2008.

Köhler, S. J., Buffam, I., Seibert, J., Bishop, K. H., and Laudon, H.: Dynamics of stream water TOC concentrations in a boreal headwater catchment: Controlling factors and implications for climate scenarios, J. Hydrol., 373, 44-56, 2009.

Laudon, H. and Buffam, I.: Impact of changing DOC concentrations on the potential distribution of acid sensitive biota in a boreal stream network. Hydrol. Earth Syst. Sci., 12, 425-435, 2008, http://www.hydrol-earth-syst-sci.net/12/425/2008/.

Laudon, H., Köhler, S., and Buffam, I.: Seasonal TOC export from seven boreal catchments in northern Sweden, Aquat. Sci., 66, 223-230, 2004a.

Laudon, H., Seibert, J., Köhler, S., and Bishop, K.: Hydrological flow paths during snowmelt: Congruence between hydrometric measurements and oxygen 18 in meltwater, soil water, and runoff, Water Resour. Res., 40, W03102, doi:03110.10292003WR10002455, 2004b.

Laudon, H., Sjöblom, V., Buffam, I., Seibert, J., and Mörth, M.: The role of catchment scale and landscape characteristics for runoff generation of boreal streams, J. Hydrol., 344, 198-209, 2007.

Laudon, H., Westling, O., and Bishop K.: Cause of $\mathrm{pH}$ decline in stream water during spring melt runoff in northern Sweden. Can. J. Fish. Aquat. Sci., 57, 1888-1900, 2000.

Lipson, D. A. and Schmidt, S. K.: Seasonal changes in an alpine soil bacterial community in the Colorado Rocky Mountains, Appl. Environ. Microb., 70, 2867-2879, 2004.

McDowell, W. H., and Likens, G. E.: Origin, Composition, and Flux of Dissolved Organic-Carbon in the Hubbard Brook Valley, Ecol. Monogr., 58, 177-195, 1988.

McGlynn, B. L. and McDonnell, J. J.: Role of discrete landscape units in controlling catchment dissolved organic carbon dynamics, Water Resour. Res., 39, 1090, doi:10.1029/2002WR001525, 2003.

Mellander, P. E., Löfvenius, M. O., and Laudon, H.: Climate change impact on snow and soil temperature in boreal Scots pine stands, Clim. Change, 85, 179-193, 2007.

Moore, T. R., Pare, D., and Boutin, R.: Production of dissolved organic carbon in Canadian forest soils, Ecosystems, 11, 740751, 2008.

Nilsson, M., Sagerfors, J., Buffam, I., Laudon, H., Eriksson, T., Grelle, A., Klemedtsson, L., Weslien, P., and Linderoth, A.: Complete carbon budgets for two years of a boreal oligotrophic minerogenic mire., Global Change Biol., 14, 1-16, 2008.

Öquist, M. G. and Laudon, H.: Winter soil frost conditions in boreal forests control growing season soil $\mathrm{CO}_{2}$ concentration and its atmospheric exchange, Global Change Biol., 14, 2839-2847, 2008.

Öquist, M. G., Sparrman, T., Klemedtsson, L., Drotz, S. H., Grip, H., Schleucher, J., and Nilsson, M.: Water availability controls microbial temperature responses in frozen soil $\mathrm{CO}_{2}$ production, Global Change Biol., 15, 2715-2722, 2009a.

Öquist, M. G., Wallin, M., Seibert, J., Bishop, K., and Laudon, H.: Dissolved Inorganic Carbon Export Across the Soil/Stream Interface and Its Fate in a Boreal Headwater Stream, Environ. Sci. Technol., 43, 7364-7369, 2009b.

Panikova, N. S., Flanaganb, P. W., Oechelc, W. C., Mastepanovd, M. A., and Christensend, T. R.: Microbial activity in soils frozen to below-39 degrees C, Soil Biol. Biochem., 38, 785-794, 2006.

Rilfors, L. and Lindblom, G.: Regulation of lipid composition in biological membranes - biophysical studies of lipids and lipid synthesizing enzymes, Colloid. Surface. B., 26, 112-124, 2002.

Rodhe, A.: On the Generation of Stream Runoff in Till Soils, Nord. Hydrol., 20, 1-8, 1989.

Sarkkola, S., Koivusalo, H., Lauren, A., Kortelainen, P., Mattsson, T., Palviainen, M., Piirainen, S., Starr, M., and Finer, L.: Trends in hydrometeorological conditions and stream water organic carbon in boreal forested catchments, Sci. Total Environ., 408, 92 $101,2009$.

Schmidt, S. K. and Lipson, D. A.: Microbial growth under the snow: Implications for nutrient and allelochemical availability in temperate soils, Plant Soil, 259, 1-7, 2004.

Scott-Denton, L. E., Rosenstiel, T. N., and Monson, R. K.: Differential controls by climate and substrate over the heterotrophic and rhizospheric components of soil respiration, Global Change Biol., 12, 205-216, 2006.

Sebestyen, S. D., Boyer, E. W., Shanley, J. B., Kendall, C., Doctor, D. H., Aiken, G. R., and Ohte, N.: Sources, transformations, and hydrological processes that control stream nitrate and dissolved organic matter concentrations during snowmelt in an upland forest, Water Resour. Res., 44, W12410, doi:10.1029/2008wr006983, 2008.

Sebestyen, S. D., Boyer, E. W., and Shanley, J. B.: Responses of stream nitrate and DOC loadings to hydrological forcing and climate change in an upland forest of the northeastern United States, J. Geophys. Res. 114, G02002, doi:10.1029/2008jg000778, 2009.

Seibert, J., Grabs, T., Köhler, S., Laudon, H., Winterdahl, M., and Bishop, K.: Linking soil- and stream-water chemistry based on a Riparian Flow-Concentration Integration Model, Hydrol. Earth Syst. Sci., 13, 2287-2297, 2009, http://www.hydrol-earth-syst-sci.net/13/2287/2009/.

Serrano, I., Buffam, I., Palm, D., Brännäs, E., and Laudon, H.: Thresholds for survival of brown trout (Salmo trutta) embryos and juveniles during the spring flood acid pulse in DOC-rich stream, T. Am. Fish. Soc., 137, 1363-1377, 2008.

Soulides, D. A. and Allison, F. A.: Effects of drying and freezing 
soils on carbon dioxide production, available mineral nutrients, aggregation, and bacterial populations, Soil Sci. Plant Nutr., 91, 291-298, 1961.

Tierney, G. L., Fahey, T. J., Groffman, P. M., Hardy, J. P., Fitzhugh, R. D., and Driscoll, C. T.: Soil freezing alters fine root dynamics in a northern hardwood forest, Biogeochemistry, 56, 175-190, doi:10.5194/bg-56-175-2001, 2001.

Vidon, P., Allan, C., Burns, D., Duval, T. P., Gurwick, N., Inamdar, S., Lowrance, R., Okay, J., Scott, D., and Sebestyen, S.: Hot Spots and Hot Moments in Riparian Zones: Potential for Improved Water Quality Management1, J. Am. Water Resour. Res., 46, 278-298, 2010.
Wong, B. L., Baggett, K. L., and Rye, A. H.: Cold-season patterns of reserve and soluble carbohydrates in sugar maple and ice-damaged trees of two age classes following drought, Botany, 87, 293-305, 2009.

Yurova, A., Sirin, A., Buffam, I., Bishop, K., and Laudon, H.: Modeling the dissolved organic carbon output from a boreal mire using the convection-dispersion equation: Importance of representing sorption, Water Resour. Res., 44, W07411, doi:0.1029/2007wr006523, 2008. 